\title{
The Failure of the Court to Protect Consumers: A Review of Consumer Dispute Resolution in Indonesia
}

\section{Syamsudin ${ }^{1}$}

Received: 17 November 2019 / Accepted: 7 September 2020/ Published online: 30 September 2020

(C) The Author(s) 2020

\begin{abstract}
Indonesia needs strong measures to protect its consumers, which leads to the creation of the Consumer Dispute Settlement Agency (BPSK) as an arbiter to settle disputes between consumers and businesses efficiently. The Indonesian Supreme Court (MARI) has set aside an alarming number of BPSK arbitral awards, putting the entire system in jeopardy. The aims of this study are to examine the empirical data on MARI's decisions in setting aside arbitral awards and analyse their decision-making process. This research shows how MARI has been interpreting the statue promulgating the BPSK very narrowly. The result of MARI's interpretation of the law has deep implications for consumer protection in Indonesia, namely that the public trust in the enforcement of Consumer Protection Law by BPSK has been severely diminishing, leaving consumers without meaningful access to justice or protection of their rights.
\end{abstract}

Keywords Arbitration decision · Consumer dispute resolution · Consumer protection

The motivation for this research comes from the large number of arbitral awards at the Consumer Dispute Settlement Agency, which the Indonesian Supreme Court has set aside. At the end of October 2017, there were around 127 arbitral awards involving consumers handed down by the Agency and which were, in turn, set aside by the Supreme Court (Andi Saputra 2017). The fact that a large number of arbitral awards have been set aside raises various questions, and suspicion, in academic circles relating to the quality of the arbitral awards handed down by the Agency. The goal of this paper is to determine whether the arbitral awards from the Agency have flaws at the classification level, which leads to so many awards being set aside by the Supreme Court.

M. Syamsudin

fh@uii.ac.id; m.syamsudin@uii.ac.id

1 Faculty of Law, Universitas Islam Indonesia (UII), J1. Tamansiswa No.158, PO Box 1133,

Yogyakarta 55151, Indonesia 
The Indonesian Supreme Court has overturned a large number of the Agency's awards, and this will have serious implications for consumer protection in Indonesia. Consumers who seek recourse before the Settlement Agency will seemingly face certain disappointment when the Supreme Court overturns their arbitral awards. Experience to date suggests that this has resulted in losses for those consumers whose grievances have ignored and left them unprotected. This highlights how consumer protection in Indonesia provides a miniscule degree of legal certainty. This is in stark contrast to the notion of consumer protection in Article 1 of Indonesian Law Number 8, 1999 concerning Consumer Protections, which ostensibly ensures "all efforts to ensure legal certainty for consumer protection." Many problems in relation to the arbitral tribunal's awards have caused legal uncertainty and injustice in their enforcement of Consumer Protection Law in Indonesia. The serious implications of overturning the Settlement Agency's arbitral awards need to be understood.

An analysis of why the arbitral awards are set aside needs to happen urgently to understand the problems in the field of consumer protection. It remains unclear whether the problem is down to weaknesses and errors in the Settlement Agency's substantive and procedural regulations. The search for an explanation for this phenomenon requires an in-depth study of the factors leading to the high number of overturned arbitral awards handed down by the Agency.

Various problems relating to the decision-making process by the Settlement Agency in resolving consumer disputes have affected the legality of arbitral awards. The Settlement Agency's decision-making, both procedural and substantive, has a direct impact on consumer protection in Indonesia. Therefore, this study focuses on the implications of the arbitral awards problem at the Settlement Agency for their use as an instrument of consumer protection in Indonesia. Specifically, this paper analyses whether the Settlement Agency's decisions are suitable as a means of protecting the rights and interests of consumers. The arbitral awards of the Consumer Dispute Settlement Agency, which the Indonesian Supreme Court has overturned, are the object of research.

The focus of discussion is on the factors which have caused the Indonesian Supreme Court to overturn the decision of the Settlement Agency and the effects of those cancellations for consumer protections in Indonesia?

\section{The Existence, Duty, and Authority of the Settlement Agency}

Articles 49-58 of the Consumer Protection Law regulate the role of the Settlement Agency. There are nine articles in the Consumer Protection Law regulating its existence for legal security. These articles regulate (1) the position of the Consumer Dispute Settlement Agency as an institution for resolving consumer disputes outside court, (2) requirements as a member of the Agency, (3) elements of the Agency's membership, (4) appointment to and dismissal from the Agency, (5) Secretariat, (6) duties and powers of the Agency, (7) implementation of the duties and authority of the Agency, (8) the trial mechanism and the nature of the Agency's decisions, and (9) filing objections to the Agency's decisions.

The Consumer Protection Law mandates the government to establish the Settlement Agency in the Second Level Region (Regency/City) to resolve consumer disputes outside the court (Article 49 paragraph 1 of the Consumer Protection Law). So, the existence of the Settlement Agency provides for non-litigation consumer dispute settlement. The formation of the Agency has the goal of providing an easy, swift, and low-cost settlement of consumer 
disputes with business actors. It is easy because every consumer who feels disadvantaged by a business actor can file a complaint with the Settlement Agency, whether directly, through the representation from his proxy or by his heirs. The process is swift because the Settlement Agency has a requirement to give its ruling within a period of 21 working days (Article 55 of the Consumer Protection Law). It is low-cost insofar as in the case proceedings at the Agency require no payment by consumers.

The broad mandate of the Settlement Agency is designed to address the myriad types of consumer grievances. Normally, there are 13 tasks and authorities of the Settlement Agency, which Article 52 of the Consumer Protection Law regulates, namely, (a) handling and processing settlement of consumer disputes, by means of mediation or arbitration or conciliation; (b) providing consumer protection consultations; (c) supervising the inclusion of standard clauses; (d) reporting to the general investigator in case of violations of the provisions in this law; (e) receiving complaints, both written and unwritten, from consumers regarding violations of consumer protection; (f) conducting research and examination of consumer protection disputes; (g) summoning business actors suspected of violating consumer protection; (h) summoning and presenting witnesses, expert witnesses and/or anyone who deems themselves aware of violations of the Law; (i) requesting the assistance of investigators to present business actors, witnesses, expert witnesses, or any person that the letter $\mathrm{g}$ and letter $\mathrm{h}$ refers to, who are not willing to fulfill the summons of the consumer dispute resolution Agency; (j) obtaining, examining and/or assessing letters, documents, or other evidence for investigation and/or inspection; (k) deciding and determining the presence or absence of losses on the part of consumers; (l) notifying the decision to business actors who violate consumer protection; and (m) imposing administrative sanctions on business actors violating the provisions of this law.

According to the previously listed duties and authorities, there are basically two main functions of the Consumer Dispute Settlement Agency, first and foremost as a legal body for resolving consumer disputes outside court (alternative dispute resolution) through conciliation, mediation and arbitration, and second, in its function of supervising the inclusion of a standard clause (standard contract term). In resolving consumer disputes with business actors, the Agency's decision has two divisions. First, there is the Agency's route to resolve complaints by conciliation and mediation. This route basically only confirms the contents of the settlement agreement, which the parties have agreed and which has been signed by members of each party to the dispute. Secondly, there are the Agency's arbitral awards. The Agency's arbitral award is like a court decision in general, which includes references to precedents, legal arguments, and judgments.

The Consumer Dispute Settlement Agency seeks to reach its decisions by consensus on the basis of detailed deliberations, where possible, but when the consensus is not successful, a decision can be taken by a majority vote. The results of the consumer dispute resolution by conciliation or mediation are made in a written agreement confirming the Agency's award signed by the consumer and the business actor. Decisions on conciliation and mediation do not contain administrative sanctions, while arbitral decisions may contain administrative sanctions the chairperson and members of the assembly have signed.

Meanwhile, the Agency's arbitral award is based on a consumer lawsuit against the business actor. If the lawsuit is granted by the arbitral tribunal, the business actor must be responsible for compensating for losses suffered by consumers as a result of consuming goods or services traded by the business actor (Hidayati 2008, p.175). For a successful grant of lawsuits, the ruling stipulates the obligation that business actors must perform in the form of 
fulfillment for (1) compensations as the awards refer. The form of compensation may be in the form of (a) refunds or replacement of goods and/or services of similar type or equivalent in value or to the service; (b) compensation in accordance with the provisions of the applicable laws and regulations; (c) compensation can be in the form of potentially obtainable benefits in the case of an accident, or loss of work, or temporary loss of income, or for loss of life due to physical losses, and so on; (2) administrative sanctions in the form of compensation at most Rp. 200000000 (two hundred million rupiah). Administrative sanctions are possible in respect of business actors who violate the law in the following ways: (a) failure by business actors to compensate consumers, be it in the form of refunds or replacement with similar goods or services, as well as health care or compensation for losses the consumers suffers; (b) loss occurs as a result of advertising production activities the advertising business actors carry out; (c) business actors who cannot provide after-sales service facilities under a guarantee, both in the form of parts and maintenance, as well as each provision of pre-determined guarantees. This provision applies to both business actors who trade goods or services.

Administrative sanctions as compensation are different from physical or real damages that consumers have sued through the Agency's point of view. The Consumer Dispute Settlement Agency's Assembly, in addition to having the authority to grant claims for real damages that the consumers have suffered, also has the authorizations to add compensation through the basis of these administrative sanctions. The amount of compensation depends on the value of the consumer's loss due to using, consuming, or utilizing the goods or services of the respective producers or business actors (Nugroho 2008, p.121).

According to the Decree of the Minister of Industry and Trade of the Republic of Indonesia No.350/MPP/Kep/12/2001, the Consumer Dispute Settlement Agency has the authority to impose compensation under this administrative sanction. The Agency can only charge business actors if the dispute is settled through arbitration. This is not possible in respect of the Agency's decision following conciliation or mediation on the basis of conciliation agreement letters both parties create and sign to bring the dispute to an end, making compensations unnecessary.

The Assembly has the obligation to decide on consumer disputes not later than 21 working days from the date the complaint has been received by the Settlement Agency. After they have received notification of the outcome, consumers and/or business actors in dispute must declare to accept or reject their decision no later than 7 working days after receiving the decision. If consumers and/or business actors reject their decision, then they can submit an objection to the District Court at the place of consumer's domicile no later than 14 working days from the date the decision is notified. Conversely, if consumers and business actors accept the decision, then the business actor has the obligation to execute the decision no later than seven working days after declaring receipt of the decision. With regards to the decision of the District Court in deciding objections, if the related parties do not accept the decision, then within a maximum period of 14 days, they can fill an appeal to the Supreme Court of the Republic of Indonesia.

According to the provisions of Article 54 paragraph (3) of the Consumer Protection Law and Article 42 paragraph (1) of the Decree of the Minister of Industry and Trade No.350/MPP/ $\mathrm{Kep} / 12 / 2001$, the decision is final and binding on the parties without the possibility to submit an appeal or objection. But what is ambiguous and out of sync, Article 56 paragraph (2) of the Consumer Protection Law leaves open the opportunity to submit an objection to the District Court, within a period of 14 days after the decision's notification. Problems arise because the Consumer Protection Law does not limit the grounds on which an objection to the decision may be raised. The aforementioned conditions can cause uncertainty that results in confusion 
and legal uncertainty in practice. In a judicial system such as this, the implementation of the objection legal instrument is confusing and gives rise to various perceptions, especially of judges, when there are no clear and consistent guidelines for the interpretation of the law, especially if the guidelines for implementing the law are not available in court. Therefore, there is a disparity in the decision of a consumer dispute which is basically an attempt to object to the decision, which results in its implementation being inconsistent and there is no unity of opinion from various court decisions (Rahman 2018).

\section{The Factors that Cause Arbitration Decisions at Settlement Agency to Be Set Aside by the Indonesian Supreme Court}

The focus of this paper is those arbitral awards by the Settlement Agency which the panel of cassation judges in Indonesian Supreme Court has set aside - as many as 40 decisions (Mahkamah Agung RI 2017). The selection of those decisions uses the basis of the availability of decision data at the Supreme Court which researchers can access without using sampling techniques. From the 40 reviewed decisions, 35 decisions come from the Agency in Batubara (North Sumatra); meanwhile, the Settlement Agency in Makasar (South Sulawesi), Medan (North Sumatra), Serdang Bedagai (North Sumatra), and Karawang (West Java) each has one decision. The selection of the decisions has its basis solely from the availability of decision data at the Supreme Court which researchers can access and is not based on a particular sampling methodology.

According to the contents of the decisions thus examined, the type of case that consumers have submitted to the arbitral tribunal at the Agency and which was appealed to the Supreme Court is available in Table 1 below.

Consumer complaints against banks have been the type of award most commonly set aside by the Indonesian Supreme Court. As Table 1 has detailed, these cases include banking (mortgage rights auction) (62\%), leasing (credit agreement) (32\%), and only 5\% of cases concerning non-banking goods and services disputes. In these three types of cases, the Supreme Court has overruled the awards for exceeding the Settlement Agency's jurisdiction.

The Supreme Court's actions in setting aside the majority of banking-related cases rest on its misinterpretation of the Settlement Agency's authority. The jurisdiction of the Settlement Agency is regulated in Article 52 of the Consumer Protection Law. Accordingly, the Settlement Agency has the duty and authority to handle and resolve consumer disputes, through mediation or arbitration or conciliation. Furthermore, Article 53 of the Consumer Protection Law provides that further provision may be made regarding the implementation of duties and the authority in respect of consumer dispute resolution by ministerial decree. The ministerial decree refers to the Decree of the Minister of Industry and Trade of the Republic of Indonesia

Table 1 Types of the consumer dispute submitted to BPSK and MARI

\begin{tabular}{llc}
\hline Types of the consumer dispute & Frequency & Percent (\%) \\
\hline Banking (mortgage rights auction) & 25 & 62.5 \\
Leasing (credit agreement) & 13 & 32.5 \\
Non-banking goods and services disputes & 02 & 05.0 \\
Total & 40 & 100 \\
\hline
\end{tabular}

Source: Secondary data on BPSK and MARI, 2018 
Number 350/MPP/Kep/12/2001 concerning the Implementation of the Tasks and Authority of the Settlement Agency.

The Indonesian Supreme Court has ruled that the Agency has limited jurisdiction. According to the panel of judges at the court, the arbitration panel of judges at the Settlement Agency should not have accepted these three types of cases because it is not their authority. The arbitration panel of judges at the Settlement Agency only has the authority to examine and resolve consumer disputes as Article 52 of the Consumer Protection Law stipulates and the implementation thereof is governed by the Decree of the Minister of Industry and Trade No. $350 / 2001$, which has limited the scope of consumer demands for damage, pollution, and consumer losses compensation for the purchase, use of goods or services. The Agency may not examine cases outside these provisions. Arbitration judges at the Agency have no permission to examine and settle civil cases in general, which relates to non-performance (default) and tort (acts against the law).

According to the decisions of 40 judges in Indonesian Supreme Court, several reasons the Panel of Judges have been given for setting aside the arbitral awards handed down by the Agency: (1) The arbitral panel of judges at the Agency has no authorization to examine and adjudicate the contents of the contract; (2) awards concerned types of consumer dispute heard by the Settlement Agency which have not been classified as consumer disputes under the Decree of the Minister of Industry and Trade No. 350/2001; (3) awards concerned types of disputes in the form of private disputes in general in the form of non-performance (default) and tort (acts against the law); (4) awards concerned types of disputes which do not contain an element of loss resulting from consumption of goods and/or service benefits the consumers have experienced; and (5) cases concerning bank debt disputes are not classified as consumer disputes.

There are deep divisions in the way the statute establishing the Agency could be interpreted. The research results of the arbitration decisions at the Agency and the decision at the Supreme Court find that there are differences of opinion between the arbitration panel of judges at the Agency and the panel of judges at the Supreme Court with regard to determining the limits of the scope of the term "consumer disputes." This can be seen from the basic legal considerations the two decisions have used. According to the arbitration panel of judges at the Settlement Agency, in determining the scope of consumer disputes, more emphasis is given to the impact of material losses many consumers have suffered as a result of the actions of business actors that have harmed consumers, regardless of the limitations in the Decree of the Minister of Industry and Trade Number 350/2001. As per this argument, the arbitration panel of judges at the Agency believes that this dispute is a consumer dispute, regardless of whether any consumer is the last consumer or not and does not see the loss as one caused by non-performance or tort violations.

Meanwhile, the panel of judges at the Supreme Court strongly upholds the limits of the definition of "consumer disputes" in the Decree of the Minister of Industry and Trade No. 350/ 2001, which limits this to consumer losses due to using goods or services. The legal considerations of the Panel of Judges at the Supreme Court in determining whether the case classifies in the scope of a consumer dispute does not rely on the presence or absence of an agreement, so that whatever the reason for the arbitration panel at the Agency must be set aside. The arbitration panel has, according to the judgement by the Supreme Court, applied the law incorrectly and exceeded its authority. The authority of the Settlement Agency has its limit to handling consumer dispute issues, namely the existence of an element of consumer loss due to consuming goods and or services, but not where the cause of the loss is due to default or unlawful acts. 
According to the results of the description of the research findings of these 40 decisions of the arbitral panel of judges at the Agency which are set aside by the panel of judges at the Supreme Court, the main factor causing the cancellation of an arbitral award given by the Agency stems from unclear definition of "consumer dispute." The Consumer Protection Law itself, as the basic regulation governing consumer protection, also does not clearly regulate the definition of consumer disputes. This then leads to differences in views between the Settlement Agency and the Supreme Court in examining and resolving consumer disputes. The Consumer Protection Law has clearly defined the definition of consumers and business actors, while the protection law has no clear definition for consumer disputes.

The definition of a consumer according to the Article 1 of Consumer Protection Law is "every person who uses goods and/or services available in the community, both for the benefit of themselves, their families, other people and other living things and not for trading". Furthermore, a business actor is "every individual or business entity, whether in the form of a legal entity or not a legal entity established and domiciled or carrying out activities within the jurisdiction of the Republic of Indonesia, both individually and jointly through agreements to carry out business activities in various fields." Although there is a definition of consumer dispute in Article 1 paragraph 10 of the Decree of the Minister of Industry and Trade No. 350/ 2001, the Agency does not follow that definition in deciding consumer dispute cases.

According to Article 1 paragraph 10 of the Decree of the Minister of Industry and Trade No. 350/2001, "consumer disputes are disputes between business actors and consumers who demand compensation for damage, pollution and/or who suffer losses due to consumption of goods and/or service utilization." In this regulation, elements of consumer disputes include (1) the presence of elements of consumers and business actors, (2) an element of loss, and (3) an element of effect in consuming goods and/or utilizing services.

The formulation of the definition of "consumer disputes" in the Decree of the Minister of Industry and Trade No. 350/2001 contains several elements, namely, the existence of consumers, business people, and material losses. The panel of judges at the Supreme Court appears to only pursue the consequences of consumer disputes that cause harm to consumers and does not see the cause or source of consumer disputes. Meanwhile, the arbitration panel of judges at the Agency sees the causes and sources of consumer disputes, which can occur due to non-performance or illegal actions.

Consumer disputes are essentially disputes between business actors and consumers as opposed to disputes between business actors. According to Article 1, section 11 of the Consumer Protection Law, the Consumer Dispute Settlement Agency is a body that handles and settles disputes between business actors and consumers. The provision does not provide a clear meaning of what "handling" and "settling" disputes between business actors and consumers mean. However, it is understandable that these two words relate to the Agency's work process and the output of the process. According to Article 52 of the Consumer Protection Law, there are 13 Settlement Agency duties and authorities, not all of which apparently have relations to consumer disputes. This means that the limits on the duties and authority of the Agency have been expanded through Article 52 of the Consumer Protection Law.

In resolving these consumer disputes, the Agency has the duty and authority to impose administrative sanctions on business actors who violate the Consumer Protection Law provisions. However, the sanctions are only one way, essentially aimed at business actors. The Settlement Agency does not have the authority to impose any sanctions on consumers, even for example, when consumers are wrong in their complaints or requests or lawsuits. The Agency does not have the authorization to impose non-administrative sanctions, let alone 
criminal sanctions. The Consumer Protection Law only authorizes the imposition of criminal sanctions at the district court when a case has entered the criminal law domain.

According to Article 37 of the Decree of the Minister of Industry and Trade No. 350/12/ 2001, administrative sanctions are only for the process of dispute resolution through arbitration. If the process is not arbitration, that is mediation or conciliation, the "decision" of the assembly is only a written agreement and does not contain administrative sanctions. In imposing arbitral sanctions, they will limit them in the form of determining compensations of at most Rp. 200000 000. The word "compensation" alongside the word "administrative sanctions" is present in Article 40 paragraph (3) letter b.

Even though the Consumer Dispute Settlement Agency does not have the authorization to impose non-administrative sanctions, it turns out that outside of this administrative sanction, there are "compensation sanctions" which the "administrative sanctions" does not include, i.e., if the arbitral tribunal judges the business actors to have caused damage, pollution, and/or consumer losses due to the consumption of goods and/or the utilization of services. The sanction's amount is not specified, but some pointers exist in Article 12 paragraph (2) of the Ministry of Industry and Trade No. 350/2001, namely, (1) refunds, (2) replacement of goods and/or services of similar type or equivalent value, or health care and/or compensation. In addition to the alternative options, compensation and administrative sanctions have cumulative application, as seen from the words "and/or" in Article 40 paragraph (3) letter of the Minister of Industry and Trade No. 350/2001.

The issue of administrative sanctions in relation to the duties and authority of the Consumer Dispute Settlement Agency is interesting to study, considering that Article 60 of the Consumer Protection Law has limited the authority of the Agency. The article states that the Agency has the authority to impose administrative sanctions on business actors violating Article 19 paragraph (2) and paragraph (3), Article 20, Article 25, and Article 26. Article 19 paragraph (1) of the Consumer Protection Law also needs their inclusions because the provisions in paragraphs (2) and (3) of Article 19 are from that paragraph (1). The administrative sanctions the Agency imposes as compensation consist of at most Rp. 200000000 . The procedure for determining such value in this article is present in the Decree of the Minister of Industry and Trade No. 350/2001.

Article 60 of this Consumer Protection Law clearly restricts the authority of the Settlement Agency in imposing sanctions, which limits only to administrative sanctions. Even then, it only deals with the four Consumer Protection Law articles previously mentioned, namely if: (1) Business actors do not provide compensation for damage, pollution, and/or consumer losses due to the consumption of goods and/or services produced or traded; or (2) business actors do not return money or replace goods and/or services with those of a similar or equivalent value, or health care and/or providing compensation in accordance with the provisions of the applicable laws and regulations; (3) business actors do not provide compensation within the grace period of 7 days after the date of the transaction (related to numbers 1 and 2 above); (4) business actors produce advertisements that result in losses to consumers; (5) business actors produce goods who are not durable in that they cannot be used for at least 1 year (does not provide spare parts and/or after-sales facilities and does not meet the guarantee or guarantee as promised); (6) business actors in the service sector do not fulfill the guarantees previously agreed.

From the description, it appears that the four articles, namely Article 19 paragraph (2) and paragraph (3), Article 20, Article 25, and Article 26 must be the basis of complaints/requests/ claims made to the Agency. However, in practice, the Agency has involvement in handling all submitted cases whose territories are outside the four articles. By looking at the normative provisions and practices that they carry, it shows that the regulation on the authority of the Settlement Agency, and thus their efforts must be recognizable, but is still poorly arranged 
because there are still problems cropping up, both theoretical and in their practical application (Shidarta 2018). Such a situation is the cause of the absence of legal certainty for both consumers and business actors as the objective of the Consumer Protection Law.

From the substantial aspects of the Consumer Protection Law itself, there are confusions of norms governing the nature of the Agency's decision which results in legal uncertainty. Article 54 of the Consumer Protection Law states that their decision is final and binding. However, when under Article 56 paragraph (2), there is an opportunity to submit an objection to the District Court (Helmi 2015).

The legal force of the Consumer Dispute Settlement Agency's decision is a final decision and has permanent legal force according to Article 54 paragraph (3) of the Consumer Protection Law, except for an Arbitral award that can file an objection with the basis of Article 2 of the Supreme Court Regulation Number 1 of 2006 concerning the Procedures for Filing Objection against the Agency's Decision (Mardika et al. 2014).

The regulation of legal remedies in connection with the Agency's decision is contradictory and inconsistent between the provisions of Article 54 paragraph 3 of the Consumer Protection Law on the one hand with the provisions of Article 56 paragraph 2 and Article 58 paragraph 2 of the Consumer Protection Law on the other. According to Article 54 paragraph 3 of the Consumer Protection Law, in principle, the Agency's decision is a final and binding decision. This means that the legal effort cannot be taken regarding the decision either appeal or cassation (Putra and Rudy 2013).

In comparison with the settlement of consumer disputes in several countries such as through the Small Claims Tribunal (SCT) and Small Claims Court (SCC), the Agency's authority turns out to be narrower in comparison with other settlement institutions. With that narrow authority, the Settlement Agency has to be an easy, swift, and low-cost consumer dispute resolution Agency. On the other hand, the Agency's panel of judges turns out to be more general in nature consisting of elements of government, business actors, and consumers with different backgrounds. While the SCT and SCC consist of active judges and retirees who are very knowledgeable about the problem, this has the potential to weaken the Agency as the consumer dispute resolution Agency in Indonesia (Kurniawan 2013, p.266).

The role of the Agency the Consumer Protection Law has mandated is limited. The cause is the substance of the regulation, procedure, and mechanism of dispute resolution which contains many weaknesses, as well as the lack of knowledge and concern of consumers in fighting for their rights (Hasanah 2012). Santoso and Pahroji (2012) have researched about "the Optimizing the Role and Function of the Agency in Consumer Dispute Settlement in Karawang Regency" and focus on the performance of the Agency as against the parameters for achievement of the objectives of the Agency set out when it was created. The purpose of the enactment of the Consumer Protection Law is to improve the economy and welfare of the community. However, there are some weaknesses in the Consumer Protection Law, namely, the qualifications of people occupying the assembly in the Settlement Agency are unclear and the unenforced personal code of ethics (Alkostar 2004). Bhakti (2001) highlights that the Settlement Agency as an arbitration institution still has many shortcomings. This study outlines the inhibiting and supporting factors of the Agency as seen from the passive role of the assemblies when becoming a conciliator or active when becoming a mediator or arbitrator in the process of resolving consumer disputes. Businesses and consumers if there are questions from both parties and that is about regulations in the field of consumer protection. But it can be a barrier to the inactivity of the parties to the dispute to ask questions and become a supporter when the parties to the dispute can communicate with each other. Meanwhile, the role of mediator and arbitrator is more active during the dispute resolution process. The research looks more at the role of the judges in resolving consumer disputes (Dewi 1999). 


\section{The Implication of the Settlement Agency Arbitral Award Cancellation for Consumer Protection}

The Settlement Agency is one of the consumer protection institutions that form the basis of the Consumer Protection Law's enforcement. Thus, the position of the Agency is very strong legally. For consumer protection, the existence of the Settlement Agency is very central. The Settlement Agency's task in resolving consumer disputes through mediation, conciliation, or arbitration is essentially a Small Claims Court model that focuses on resolving consumer disputes with little value. The Agency itself is an institution with tasks other than resolving consumer disputes but also providing protection for consumers through its supervisory functions.

The Settlement Agency is often the only method of seeking redress for consumers. In addition to the duties and authority of the Agency, if it is seen according to its position in Article 23 of the Consumer Protection Law that explains how "if the business actor refuses and/or does not respond and/or does not meet the demands for compensation for the demands of consumers, then consumers are given the right to suing business actors, and settling disputes arising through the Consumer Dispute Settlement Agency, or by filing a lawsuit with the judiciary in the consumer's place of residence." There are two important points: (1) The Consumer Protection Law provides an alternative settlement through a body outside the justice system and (2) the settlement of consumer disputes with business actors is not an executive choice that does not have to be chosen. The choice of dispute resolution through the Agency is parallel or parallel to the choice of dispute resolution through the judiciary (Shofie 2002). According to the description of the two points above, it can be understood that the Consumer Protection Law has given an equal position to the Settlement Agency with the judiciary in dispute resolution so that the Agency has competencies that must be recognized and respected by other institutions.

This is the basis for the Consumer Protection Law mandating the establishment of a Settlement Agency in every district or city government throughout Indonesia. The Agency is an independent institution whose function is to resolve consumer disputes outside the court and also supervise the inclusion of standard clauses. The duties and authority of the Agency have their regulations written in Article 52 of the Consumer Protection Law, with the implementer's regulations in the Decree of the Ministry of Trade No. 350/2001, which also regulates procedural law to resolve consumer disputes at the Agency.

The Consumer Dispute Settlement Agency as a dispute settlement professionals certainly has an output in the form of a consumer dispute resolution decision. The decision of the Agency has its regulation by Article 42 paragraph (1) of the Ministry of Trade No. 350/2001. In this provision, the regulation states that the Agency decision is final and has permanent legal force. Final means the settlement of disputes made through the Agency must end and be settled at the Agency, while decisions that have permanent legal force are those that according to the provisions of the law, there is no more opportunity to use ordinary legal remedies against these decisions. In other words, the decision cannot be contested. In this decision, which has become permanent, there are three kinds of power, namely, binding, evidential, and implementation strength. In other words, as long as the decision has not obtained permanent legal force, the efforts and actions of the execution have not functioned.

The Consumer Dispute Settlement Agency Assembly's decision divides into three types of decisions, namely, the Agency's decision by conciliation, mediation, or arbitration. The difference relates to the substance of the content of the decision. The decision of the Settlement Agency by means of arbitration contains the sitting of the case and its legal considerations, 
while the decision by conciliation and mediation issue solely on the basis of the conciliation agreement letter that both parties of the disputes make and sign (Article 42 of the Decree of the Minister of Industry and Trade No. 350/2001).

Final means settlement of disputes made through the Agency's must end or be resolved at the Settlement Agency, and legal proceedings may not be made by both parties to the dispute. The principle of res judicata vitatate habetur (a decision that is no longer possible for legal remedies is stated as a decision that has permanent legal force) applies. According to this principle, the Settlement Agency's decisions must be viewed as decisions that have permanent legal force.

However, there is a juridical irregularity in Article 56 paragraph (2) of the Consumer Protection Law as if placing the Agency as the first-level adjudicating body, while the District Court is an appellate court. In addition, the parties are also given a broader opportunity to file an appeal without having to be seen whether they are business actors or consumers. The objection referred to in Article 56 paragraph (2) of the consumer protection is none other than the remedies appeal as stipulated in the civil procedural law in force in the general court (Nugroho 2008, p.339).

Another irregularity is that in order for the Agency decision to have the power of execution, the decision must be requested to determine the fiat execution in the district court in the residence of the injured consumer (Putranto 2019, p.180). In practice, difficulties arise to request fiat execution through the District Court due to various reasons raised by the District Court, among others: (1) The Agency's decision does not contain the words "In favor of justice based on the Almighty God" so that it cannot be executed; (2) there are no regulations or instructions on the procedure for submitting requests for execution of the Agency's decision; and (3) the strength of the Agency's decisions that are final and binding has not entirely been able to guarantee legal protection for consumers (Badawi et al. 2013).

As it is known that the rules relate to the Agency in the Consumer Protection Law and the Ministry of Trade Decree No. 350/2001 along with other implementing regulations are minimal, unclear, and even some of the substances are conflicting. Seeing the phenomenon of the executive power of the Agency's decision and its unclear law, it ensures that the functions, duties, and authority of the Agency are not running effectively, and it is necessary to formulate ideas for effective and efficient consumer dispute resolution institutions. This is solely to realize certainty and effectiveness in consumer protection in Indonesia.

Effectiveness in the field of law means talking about the workings of the law itself in regulating and/or forcing people to obey the law. The law can be effective if the factors that influence the law can function as well as possible. The effective measure of whether a law or regulation applies can be seen from the behavior of the community. A law or regulation will be effective if the community members behave as expected or desired by the law or regulation to achieve the desired goal. In that case, the effectiveness of the law or regulation has been achieved (Syamsudin et al. 2017).

The large number of reversals of the Agency's arbitral awards by the cassation panel of judges at the Indonesian Supreme Court, directly or indirectly, has had quite a broad impact, especially in terms of law enforcement of consumer protection in Indonesia. The impact according to the author's analysis can be summarized as follows: First, the large number of reversals of the Agency's decision by the Supreme Court shows how weak the Agency's legal decisions are. This will reduce the level of public trust in the Settlement Agency. Secondly, the phenomenon of the setting aside of the Agency decisions shows the lack of synchronization between the authority of the Agency as the Consumer Protection Law grants, and the scope of competence in the judicial framework, thus affecting the ineffective enforcement of Consumer 
Protection Law by the Settlement Agency. Third, the reversal of the Agency's decisions, due to the absence of clear boundaries, has rigid regulations in the main legal norms (Law), causing chaos in the interpretation of consumer disputes themselves, especially their limitations and scope, causing a conflict of authority between the judiciary and the Settlement Agency.

\section{Conclusion and Suggestion}

According to the findings of the research, the following becomes clear: Firstly, there are several factors that cause the Agency's arbitral awards to be set aside by the Indonesian Supreme Court. One factor is the Supreme Court's perversely narrow interpretation of the Agency's jurisdiction. Furthermore, there is a persistent dispute between the arbitration panel judges at the Agency and the justices at the Supreme Court. In considering its decision, whereas the decision of the arbitral panel of judges at the Agency looks more at the cause of consumer disputes that cause material losses to consumers, whether due to non-performance or illegal actions by the business actors. In contrast, the panel of judges in the Supreme Court emphasize the consequences arising from consumer disputes that causes material losses to consumers according to the Decree of the Minister of Industry and Trade No. 350/2001. Also, the Consumer Protection Law does not clearly regulate the definition of consumer disputes. This is the source of the differences of views between the arbitration panel of judges at the Agency and the panel of judges at the Supreme Court regarding the meaning and limits of consumer disputes.

Secondly, the large number of annulments of arbitral decisions given by the Settlement Agency by Indonesian Supreme Court has implications for consumer protection in Indonesia. In particular, consumer's expectations to obtain their rights against business actors have failed, and thus, consumers do not receive adequate legal protection. This will have an impact on the decline in the level of consumer confidence in the Settlement Agency. In turn, the Agency's standing as an alternative to settle consumer disputes is weakened by the Indonesian Supreme Court's position with regard to the authority of the Agency. Finally, the Consumer Protection Law's aim of resolving consumer disputes easily, swiftly, and at low cost is not realized.

The conclusion of this paper is as follows: First, it is necessary to clarify and legally ensure the duties and authority of the Settlement Agency by reviewing the Consumer Protection Law and to ensure that its implementing regulations do not overlap. Secondly, in practice, many consumers submit their cases to the Agency without seeing whether this is a breach of contract or an illegal act. Therefore, it is necessary to increase the duties and authority of the Settlement Agency so that it can expand in order to handle the problem of defaults and illegal actions that are detrimental to consumers so that consumers truly get legal protection by the Agency's decision. Third, if an arbitration mechanism conducts consumer disputes at the Agency and then one of the parties submits to the cassation level, the panel of judges at the Indonesian Supreme Court must carefully examine the subject matter of the case, not necessarily setting aside the decision by stating that the Agency has exceeded its authority, which will result in consumers without acquiring their justices and legal protections.

Acknowledgments The researcher would like to thank the Directorate of Research and Community Service at the Universitas Islam Indonesia (UII) for funding this research. Thanks also to Riky Rustam, Nur Laili Dwi Kuncoro, and Rachma Fadlillah for helping with research data collection. 
Open Access This article is licensed under a Creative Commons Attribution 4.0 International License, which permits use, sharing, adaptation, distribution and reproduction in any medium or format, as long as you give appropriate credit to the original author(s) and the source, provide a link to the Creative Commons licence, and indicate if changes were made. The images or other third party material in this article are included in the article's Creative Commons licence, unless indicated otherwise in a credit line to the material. If material is not included in the article's Creative Commons licence and your intended use is not permitted by statutory regulation or exceeds the permitted use, you will need to obtain permission directly from the copyright holder. To view a copy of this licence, visit http://creativecommons.org/licenses/by/4.0/.

\section{References}

Alkostar, A. (2004). Paradigmatic phenomenon of the court in Indonesia. Critical study of consumer dispute decisions. Legal Journal of IUS QUIA IUSTUM, 11(26), 2004.

Badawi, A.FF, Setyawan, F., \& Wahjuni, E. (2013). Juridical review of the legal strength of BPSK according to Law Number 8 of 1999 concerning consumer protection (Paper at the Faculty of Law, University of Jember (UNEJ)).

Bhakti, Y. (2001). Some notes on arbitration dispute settlement bodies. Journal of Media Law, 8(2), 2001.

Dewi, P.W.S. (1999). The role of BPSK in consumer dispute settlement under Law No.8 Year 1999. Study of consumer dispute resolution in the Bandung City (Thesis at the Diponegoro University, Semarang Master of Law Program).

Hasanah, U. (2012). The role of the Consumer Dispute Settlement Agency (BPSK) in upholding consumer rights based on the UUPK. Journal of Business Applications, 3(1), 2012.

Helmi, H. R. (2015). The existence of BPSK in resolving consumer disputes in Indonesia. ADHAPER Civil Procedure Journal, 1(1), 2015.

Hidayati, M. N. (2008). Analysis of alternatives to consumer protection dispute resolution: Study of the effectiveness of the Consumer Protection Dispute Resolution Board. Lex Jurnalica, 5(3).

Kurniawan. (2013). Comparison of consumer dispute settlement in Indonesia with the European legal system (Perbandingan Penyelesaian Sengketa Konsumen di Indonesia dengan Negara-Negara Common Law System). Jurnal Hukum dan Pembangunan, 43(2), 247-269.

Mardika, D., Putra, I. G., \& Ariyana. (2014). The legal strength of BPSK's decision as a small claim court institution in consumer dispute settlement. Kertha Semaya Journal, 01(01).

Nugroho, S. A. (2008). The process of consumer dispute resolution in judgment of the procedure law and its constraints to implementation. Jakarta: Kencana Prenada Media Group.

Putra, I. P. I. K., Wiryawan, I.W., \& Rudy, D. G. (2013). Regulation of legal efforts and execution of BPSK decisions (Pengaturan Upaya Hukum dan Ekseskusi Putusan Badan Penyelesaian Sengketa Konsumen (BPSK). Kertha Semaya: Jurnal Ilmu Hukum, 1(1), 9-17.

Putranto, I. A. (2019). Legal review of the implementation of BPSK decisions in district courts. Journal of Legal Issues, 48(2), 2086-2695.

Rahman, A. (2018). Settlement of consumer disputes via Serang City Consumer Dispute Settlement Agency (BPSK). AJUDIKASI: Journal of Legal Studies, 2(1).

Santoso, I. B., \& Pahroji, D. (2012). Optimization of the role and function of BPSK in Consumer Dispute Resolution in Karawang Regency (Optimalisasi Peran dan Fungsi BPSK dalam Penyelesaian Sengketa Konsumen di Kabupaten Kerawang). Jurnal Solusi Unsika, 11(24), 12-19.

Shidarta. (2018). The Authority of BPSK versus LAPS-OJK. Retrieved from http://business-law.binus.ac. id/2018/08/18/kewenang-bpsk-versus-laps-ojk/. Accessed 10 July 2019.

Shofie, Y. (2002). Settlement of consumer disputes according to the Consumer Protection Act (UUPK). Theory and practice of law enforcement. Bandung: PT. Citra Aditya Bakti.

Syamsudin, M., Anto, M. B. H., Kurniyanto, M. N. L. D., \& Puspitasari, I. (2017). An effective supervision model of a standard clause for consumer protection in the business transaction. Hasanuddin Law Review, 3 (1), 36-48

Mahkamah Agung RI (2017). Informasi Perkara. Retrieved from https://kepaniteraan.mahkamahagung.go. id/perkara/. Accessed 4 Jul 2018.

Andi Saputra (2017). Tok! 127 Keputusan Sengketa Konsumen Dianulir MA. Retrieved from https://news.detik. com/berita/d-3669668/tok-127-keputusansengketa-konsumen-dianulir-ma?utm_source=whatsapp\&utm campaign=detikcomsocmed\&utm_medium=btn\&utm_content=news. Accessed 10 Aug 2018. 


\section{Legislation}

\section{Indonesia}

Arbitration and Alternative Dispute Resolution Act 1999

Consumer Protection Act 1999

Decree of the Minister of Industry and Trade 2001/350 on the Implementation of Duties and Authorities of the Consumer Dispute Resolution Board

Publisher's Note Springer Nature remains neutral with regard to jurisdictional claims in published maps and institutional affiliations. 